\title{
PENERAPAN MODEL PEMBELAJARAN INDEX CARD MATCH PADA BIDANG STUDI PENDIDIKAN AGAMA ISLAM DAN BUDI PEKERTI UPAYA MENINGKATKAN HASIL BELAJAR PESERTA DIDIK KELAS V SEMESTER SATU TAHUN PELAJARAN 2018/2019 DI SD NEGERI 12 AMPENAN
}

\author{
Masni \\ Guru Pendidikan Agama Islam Dan Budi Pekerti SD Negeri 12 Ampenan
}

\begin{abstract}
Abstrak. Penelitian ini bertujuan untuk mengetahui efektifitas penerapan Model Pembelajaran Index Card Macth dalam upaya meningkatkan hasil belajar Pendidikan Agama Islam Dan Budi Pekerti Kelas V SD Negeri 12 Ampenan. Manfaat penelitian ini adalah sebagai bahan kajian dan bahan temuan dalam pelaksanaan proses pembelajaran di kelas senyatanya. Bagi guru untuk meningkatkan kompetensi dalam proses pembelajaran dan bagi peserta didik untuk meningkatkan hasil belajar peserta didik.Penelitian ini dilaksanakan dua siklus, masing-masing siklus kegiatannya adalah; perencanaan, pelaksanaan, observasi dan refleksi. Hasil akhir tindakan pada siklus II menunjukkan bahwa hasil observasi guru memperoleh skor rata-rata $(4,65)$ dan hasil observasi siswa mencapai skor rata-rata (4,54. Sedangkan dampak dari peningkatan motivasi belajar adalah meningkatnya perolehan hasil belajar siswa mencapai nilai rata-rata $(91,17)$, artinya indikator keberhasilan $(\geq 4,0)$ telah terlampaui. Karena indicator keberhasilan telah terbukti penelitian dinyatakan berhasil dan dihentikan pada siklus II.
\end{abstract}

\section{Kata Kunci : Hasil Belajar-Model Pembelajaran Index Card Macth.}

\section{PENDAHULUAN}

\section{Latar Belakang}

Upaya memandirikan peserta didik untuk belajar, bekerjasama, dan menilai diri sendiri diutamakan agar peserta didik mampu membangun kemauan, pemahaman, dan pengetahuan. Peningkatan potensi, kecerdasan, dan minat peserta didik perlu terus menerus di upayakan (Depdiknas, 2004; 3). Upaya yang konkrit yang dapat diwujudkan adalah menciptakan pembelajaran yang aktif, kreatif, efektif dan menyenangkan.

Pola pembelajaran mata pelajaran Pendidikan Agama Islam Dan Budi Pekerti di SD Negeri 12 Ampenan selama ini cenderung mengarah ke guru sentries. Pola ini yang biasa diterapkan karena model pembelajaran ini menjadikan guru adalah satu-satunya orang yang memiliki kekuasaan abadi dalam proses pembelajaran di kelas. Guru dengan berapi-api dan semangat patriotik menyampaikan materi pembelajaran dengan gaya yang beranekaragam sementara peserta didik duduk manis mendengarkan penjelasan guru dari awal sampai berakhirnya jam pelajaran. Peserta didik dianggap seperti "tabula rasa" yaitu seperti kertas putih bersih dan masih kosong yang diisi ilmu yang berasal dari guru semata.

Kondisi sebagaimana yang dipaparkan diatas, sama yang dialami oleh kebanyakan peserta didik Kelas V SD Negeri 12 Ampenan, selama proses pembelajaran peserta didik cenderung pasif, ketika guru bertanya tidak ada yang berani menjawab, ketika guru meminta peserta didik untuk menanyakan hal-hal yang belum tau/belum jelas semua diam, ketika guru menjelasskan materi pelajaran, ada yang tidur, ada yang main-main, ada pula yang SMS-an, ada yang saling lempar kertas, bermain cinta. Kondisi yang paling parah adalah ketika diberi tugas untuk mengerjakan soal banyak yang cuek.

Faktor penyebab kondisi diatas adalah kurang aktifnya peserta didik dalam proses pembelajaran di kelas senyatanya, yang di picu dari model pembelajaran yang diterapkan oleh guru cenderung mengarah keguru aktif bukan peserta didik aktif. Peserta didik sebagai objek 
pembelajaran bukan sebagai subjek pembelajaran. Peserta didik menerima teori bukan menentukan teori. Peserta didik cenderung menghafal dari apa yang diberikan oleh guru bukan sebuah gagasan yang muncul dari keaktifan peserta didik selama proses pembelajaran. Materi pembelajaran cenderung mengarah pada ke kognitif bukan afektif atau psikomotorik. Peserta didik menerima bahan jadi bukan proses belajar pemecahan masalah (problem solving learning), peserta didik mendapat materi seutuhnya dari guru bukan hasil dari proses "Discoveri Inguiry".

Banyak solusi yang dapat dilakukan guna mengatasi permasalahan kurang aktifnya belajar Pendidikan Agama Islam Dan Budi Pekerti peserta didik Kelas V SD Negeri 12 Ampenan yaitu dengan menerapkan model pembelajaran Index Card Match. Model pembelajaran ini peserta didik belajar dengan membentuk kelompok kecil. Di dalam kelompok itu peserta didik dapat saling asah, saling asuh dalam memecahkan permasalahan yang diberikan oleh guru.

Untuk membuktikan pernyataan diatas, maka perlu diadakan penelitian tindakan kelas (PTK) dengan menerapkan Index Card Match dalam upaya meningkatkan hasil belajar Pendidikan Agama Islam Dan Budi Pekerti peserta didik Kelas V SD Negeri 12 Ampenan Semester satu tahun pelajaran 2018/2019. Sehubungan dengan itu maka penelitian tindakan kelas (PTK) ini berjudul "Penerapan Model Pembelajaran Index Card Match Pada Bidang Studi Pendidikan Agama Islam Dan Budi Pekerti Upaya Meningkatkan Hasil Belajar Peserta Didik Kelas V Semester Satu Tahun Pelajaran 2018/2019 Di SD Negeri 12 Ampenan".

\section{Rumusan Masalah}

"Apakah model pembelajaran Index Card Match dapat meningkatkan hasil belajar Pendidikan Agama Islam Dan Budi Pekerti peserta didik Kelas V SD Negeri 12 Ampenan Semester satu tahun pelajaran 2018/2019.

\section{Tujuan penelitian}

- Untuk mengetahui sejauh mana efektivitas penerapan model pembelajaran Index Card Match dalam upaya meningkatkan hasil belajar Pendidikan Agama Islam Dan Budi Pekerti peserta didik Kelas V SD Negeri 12 Ampenan.

- Untuk mengetahui peningkatan hasil belajar peserta didik Kelas V SD Negeri 12 Ampenan tahun pelajaran 2018/2019 sebagai dampak dari penerapan model pembelajaran Index Card Match.

\section{Manfaat Penelitian}

- Bermanfaat bagi guru selaku peneliti dalam rangka melaksanakan proses pembelajaran yang kontekstual melalu penerapan model pembelajaran Index Card Match di kelas senyatanya serta dalam upaya perwujudan pembelajaran yang aktif, inovatif, kreatif, efektif, dan menyenangkan (PAIKEM) sehingga motivasi peserta didik dapat ditingkatkan.

- Bagi peserta didik sangat bermanfaat dalam upaya peningkatan hasil belajar yang berdampak meningkatnya prestasi belajar peserta didik.

\section{KAJIAN PUSTAKA}

\section{Hasil belajar}

Mukhtar (2003:54) mengatakan bahwa pengertian hasil belajar tidak dapat dipisahkan dan apa yang terjadi dalam aktifitas pembelajaran baik di kelas maupun diluar kelas. Apa yang dialami oleh peserta didik dalam proses pengembangan kemampuannya merupakan apa yang diperoleh dalam belajar dan pengalaman tersebut pada akhirnya dipengaruhi oleh beberapa faktor diantaranya keadaan kognitif, afektif dan psikomotornya pada waktu belajar. Kualitas pengajaran yang diterimanya dan cara pengelolaan proses interaksi yang dilakukan oleh guru.

Pakar pendidikan lain mendefinisikan bahwa yang dimaksud hasil belajar adalah perubahan perilaku secara keseluruhan bukan salah satu aspek potensi kemanusiaan saja (Supriyono, 2009:19). Berbeda dengan pendapatnya Bloom (Dalam Sumiati danAska, 
2008). Hasil belajar mencakup kemampuan kognitif, afektif, dan psikomotorik. Jadi pendapat ini mengisyaratkan bahwa haasil belajar peserta didik harus diukur dengan tes tertulis, tes sikap, dan kemampuan skil secara nyata selama proses pembelajaran di kelas senyatanya.

Dalam penelitian ini yang dimaksud dengan hasil belajar adalah tugas dan tes ulangan harian yang dilaksanakan secara tertulis pada akhir pembelajaran.

\section{Index Card Match}

\section{Langkah-langkah penerapan:}

1. Buatlah potongan-potongan kertas sejumlah peserta dalam kelas dan kertas tersebut dibagi menjadi dua kelompok.

2. Tulis pertanyaan tentang materi yang telah diberikan sebelumnya pada potongan kertas yang telah dipersiapkan. Setiap kertas satu pertanyaan.

3. Pada potongan kertas yang lain, tulislah jawaban dari pertanyaan-pertanyaan yang telah dibuat.

4. Kocoklah semua kertas tersebut sehingga akan tercampur antara soal dan jawaban.

5. Bagikan setiap peserta satu kertas. Jelaskan bahwa ini aktivitas yang dilakukan berpasangan. Sebagai peserta akan mendapatkan soal dan sebagian yang lain akan mendapatkan jawaban.

6. Mintalah peserta untuk mencari pasangannya. Jika sudah ada yang menemukan pasangannya, mintalah mereka untuk duduk berdekatan. Jelaskan juga agar mereka memberikan materi yang mereka dapatkan kepada teman yang lain.

7. Setelah semua peserta menemukan pasangan dan duduk berdekatan, mintalah setiap pasangan secara bergantian membacakan soal yang diperoleh dengan suara keras kepada teman-teman lainnya. Selanjutnya soal tersebut dijawab oleh pasangannya. Demikian seterusnya.

8. Akhiri proses ini dengan klarifikasi dan kesimpulan serta tindak lanjut.

Tujuan penerapan model pembelajaran ini adalah untuk melatih peserta didik agar lebih cermat dan lebih kuat pemahamannya terhadap suatu materi pokok.

\section{Hipotesis Tindakan.}

Penerapan model pembelajaran Index Card Match dapat meningkatkan hasil belajar Pendidikan Agama Islam Dan Budi Pekerti peserta didik Kelas V SD Negeri 12 Ampenan Semester satu tahun pelajaran 2018/2019.

\section{METODE PENELITIAN}

\section{Setting Penelitian}

Penelitian tindakan kelas (PTK) ini akan dilaksanakan di Kelas V SD Negeri 12 Ampenan Semester satu Tahun pelajaran 2018/2019, dengan jumlah peserta didik sebanyak 30 orang.

\section{Faktor yang Diteliti}

- Faktor Guru: yaitu dengan mengganti cara guru membuat Rencana Pelaksanaan Pembelajaran (RPP) dan pelaksanaannya dalam pembelajaran di kelas senyatanya dengan menerapkan model pembelajaran Index Card Match dalam upaya meningkatkan hasil belajar Pendidikan Agama Islam Dan Budi Pekerti peserta didik Kelas V SD Negeri 12 Ampenan.

- Faktor Peserta didik: yaitu peningkatan hasil belajar peserta didik yang terlihat pada perilaku peserta didik selama diskusi kelompok, dan pada saat mengerjakan tes tertulis.

\section{Rencana Tindakan}

Tindakan nyata yang dilakukan oleh guru selaku peneliti adalah dengan menggunakan siklus. Gambaran siklus dalam penelitian ini adalah sebagai berikut:

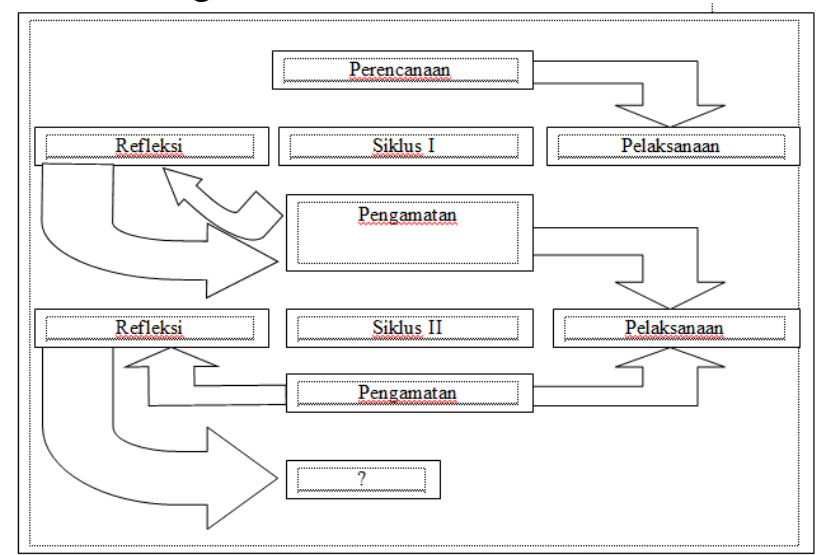


Setiap siklus selama penelitian ini berisi 4 (empat) tahapan yaitu: 1) Perencanaan (Planning), 2) Pelaksanaan (Action), 3) Observasi (Observation), dan 4) Refleksi (Reflection).

\section{Siklus Tindakan}

\section{SIKLUS I}

\section{Tahap Perencanaan (Planning)}

1. Menyusun Rencana Pelaksanaan Pembelajaran (RPP) dengan skenario sesuai dengan aturan main model pembelajaran Index Card Match.

2. Menyiapkan sumber, bahan, dan semua alat yang digunakan dalam penelitian.

3. Menyusun/membuat lembar observasi guru dan lembar observasi peserta didik.

4. Menyusun alat evaluasi.

Tahap Pelaksanaan (Action)

\section{Pertemuan I}

1. Buatlah potongan-potongan kertas sejumlah peserta dalam kelas dan kertas tersebut dibagi menjadi dua kelompok.

2. Tulis pertanyaan tentang materi yang telah diberikan sebelumnya pada potongan kertas yang telah dipersiapkan. Setiap kertas satu pertanyaan.

3. Pada potongan kertas yang lain, tulislah jawaban dari pertanyaan-pertanyaan yang telah dibuat.

4. Kocoklah semua kertas tersebut sehingga akan tercampur antara soal dan jawaban.

5. Bagikan setiap peserta satu kertas. Jelaskan bahwa ini aktivitas yang dilakukan berpasangan. Sebagai peserta akan mendapatkan soal dan sebagian yang lain akan mendapatkan jawaban.

\section{Pertemuan II}

1. Mintalah peserta untuk mencari pasangannya. Jika sudah ada yang menemukan pasangannya, mintalah mereka untuk duduk berdekatan. Jelaskan juga agar mereka memberikan materi yang mereka dapatkan kepada teman yang lain.

2. Setelah semua peserta menemukan pasangan dan duduk berdekatan, mintalah setiap pasangan secara bergantian membacakan soal yang diperoleh dengan suara keras kepada teman-teman lainnya. Selanjutnya soal tersebut dijawab oleh pasangannya. Demikian seterusnya.

3. Akhiri proses ini dengan klarifikasi dan kesimpulan serta tindak lanjut

4. Tes tertulis

Tahap Observasi (Observation)

- Observasi guru : Dilakukan oleh pengawas mata pelajaran Pendidikan Agama Islam Dan Budi Pekerti selaku observer sekaligus sebagai pembimbing guru dalam melaksanakan Penelitian Tindakan Kelas (PTK).

- Observasi Peserta didik : Dilaksanakan oleh guru mata pelajaran sekaligus sebagai peneliti dalam Penelitian Tindakan Kelas (PTK) pada kegiatan diskusi kelompok.

\section{Tahap Refleksi (Reflection)}

1. Renungan hasil perolehan data

2. Pengolahan dan analisa data hasil penelitian

3. Mencocokkan hasil analisa data dengan indikator keberhasilan

4. Rencana perbaikan dan tindak lanjut SIKLUS II

Pada siklus ini semua kegiatan dan tahapan selama penelitian adalah sama, sifatnya mengulang dan memperbaiki terhadap tindakan yang masih memerlukan penyempurnaan dan pembenaran sebagaimana mestinya.

\section{Data dan Cara Pengambilannya.}

\section{Sumber Data}

Yang menjadi sumber data dalam penelitian tindakan kelas (PTK) ini adalah semua peserta didik Kelas V Semester satu tahun pelajaran 2018/2019 di SD Negeri 12 Ampenan dan semua tim peneliti.

\section{Jenis Data}

- Jenis data yang berasal dari guru selaku peneliti

1. Data tentang Rencana Pelaksanaan Pembelajaran (RPP)

2. Data Pelaksanaan Pembelajaran

- Jenis data yang berasal dari peserta didik :

1. Data kemajuan motivasi dari peserta didik

2. Data hasil belajar peserta didik

\section{Cara Pengambilan data}


- Data kegiatan pembelajaran diambil dari RPP yang dibuat oleh guru dan lembar observasi pelaksanaan model pembelajaran Index Card Match.

- Data kemajuan hasil belajar; diambil dari lembar observasi selama diskusi kelompok.

- Data kemajuan hasil belajar; diambil dari nilai pada saat tes tertulis yang dilaksanakan pada akhir proses pembelajaran.

\section{Indikator Keberhasilan dan Teknik analisa data}

\section{Teknik analisa data}

Untuk menganalisis data akan dilakukan melalui analisis deskriptif kuantitatif melalui pendataan, analisis dan pembahasan terhadap data yang diperoleh dengan mencocokkan tingkat keoptimalan terhadap capaian indikator keberhasilan yang ada.

\section{Indikator Keberhasilan}

- guru telah dinyatakan berhasil melaksanakan proses pembelajaran dengan model pembelajaran Index Card Match, bila telah mencapai skor rata-rata $\geq 4,00$

- Hasil belajar Pendidikan Agama Islam Dan Budi Pekerti peserta didik Kelas V dinyatakan telah meningkat jika $\geq 85 \%$ dari jumlah peserta didik telah memperoleh skor perolehan skor rata-rata $\geq 4,0$, hasil belajar dinyatakan meningkat jika $\geq 85 \%$ dari jumlah peserta didik memperoleh nilai ratarata $\geq 75,00$ (Sesuai KKM)

\section{HASIL DAN PEMBAHASAN DESKRIPSI SIKLUS I}

\section{Tahap Perencanaan}

Pada tahapan ini yang telah dilakukan oleh guru selaku peneliti adalah; 1) menyusun RPP dengan skenario pembelajaran Index Card Match, 2) telah berhasil menyiapkan alat, sumber, bahan yang diperlukan dalam penelitian, 3) berhasil menyusun instrument observasi guru dan instrument observasi peserta didik, dan 4) menyusun alat evaluasi.

\section{Tahap Pelaksanaan}

1. Buatlah potongan-potongan kertas sejumlah peserta dalam kelas dan kertas tersebut dibagi menjadi dua kelompok.
2. Tulis pertanyaan tentang materi yang telah diberikan sebelumnya pada potongan kertas yang telah dipersiapkan. Setiap kertas satu pertanyaan.

3. Pada potongan kertas yang lain, tulislah jawaban dari pertanyaan-pertanyaan yang telah dibuat.

4. Kocoklah semua kertas tersebut sehingga akan tercampur antara soal dan jawaban.

5. Bagikan setiap peserta satu kertas. Jelaskan bahwa ini aktivitas yang dilakukan berpasangan. Sebagai peserta akan mendapatkan soal dan sebagian yang lain akan mendapatkan jawaban.

6. Mintalah peserta untuk mencari pasangannya. Jika sudah ada yang menemukan pasangannya, mintalah mereka untuk duduk berdekatan. Jelaskan juga agar mereka memberikan materi yang mereka dapatkan kepada teman yang lain.

7. Setelah semua peserta menemukan pasangan dan duduk berdekatan, mintalah setiap pasangan secara bergantian membacakan soal yang diperoleh dengan suara keras kepada teman-teman lainnya. Selanjutnya soal tersebut dijawab oleh pasangannya. Demikian seterusnya.

8. Akhiri proses ini dengan klarifikasi dan kesimpulan serta tindak lanjut.

Selama peserta didik menemukan pasangannya, guru melakukan penyeimbangan peningkatan/kemajuan hasil belajar peserta didik yang meliputi aktivitas peserta didik selama proses pembelajaran berlangsung dan hasil tes tertulis.

\section{Tahap Observasi}

Observasi guru memperoleh skor ratarata pertemuan I $(3,57)$ dan pertemuan II $(3,79)$, observasi peserta didik memperoleh skor ratarata pertemuan I $(3,43)$ dan pertemuan II $(3,67)$. Dampak dari hasil peningkatan hasil belajar dari tugas dan nilai tes tertulis memperoleh nilai rata-rata masing-masing sebesar $(69,13)$ dan $(66,33)$.

\section{Tahap Refleksi}

Pada tahapan ini peneliti melakukan kegiatan refleksi sebagai dampak dari 
perolehan data hasil observasi guru, observasi peserta didik, serta rata-rata nilai tes tertulis sebagai berikut:

1. Renungan data hasil perolehan data pada siklus I

2. Pengolahan data hasil observasi guru, peserta didik dan tes tertulis.

3. Mencocokkan hasil yang ada dengan Indikator keberhasilan.

4. Merencanakan perbaikan terhadap jenis tindakan yang menyebabkan belum tuntas Indikator keberhasilan. Oleh karena Indikator keberhasilan belum terbukti maka penelitian dilanjutkan ke siklus II.

\section{Deskripsi Siklus II}

\section{Tahap Perencanaan}

Pada tahapan ini jenis kegiatan yang dilakukan masih mengacu pada kegiatan siklus I, bedanya hanya terjadi perbaikan seperlunya yaitu: 1) penyusunan RPP dengan mengacu pada model pembelajaran Index Card Match dan penyempurnaan pada bagian skenario pembelajaran, 2) menyiapkan alat, sumber, bahan yang diperlukan dalam proses tindakan dikelas senyatanyan, 3) menyiapkan lembar observasi guru dan lembar observasi peserta didik sebagaimana pada siklus I, 4) menyiapkan alat evaluasi sebagaimana yang telah dibuat pada siklus I.

\section{Tahap Pelaksanaan}

Secara umum tahapan pelaksanaan proses pembelajaran pada siklus II ini masih mengacu pada pelaksanaan proses pembelajaran sebelumnya. Pemecahan yang dilakukan pada proses pembelajaran ini adalah: 1) pelaksanaan proses diskusi kelompok kecil lebih dioptimalkan, 2) pelaksanaan pembimbingan kelompok sekaligus observasi peserta didik lebih di efektifkan. Utamanya pengamatan peserta didik yang termotivasi, yang kurang motivasi, peserta didik yang tidak termotivasi, dengan harapan proses analisa data lebih signifikan, 3)laporan hasil kerja kelompok yang dibuat secara individu lebih difokuskan, dan 4) pelaksanaan tes tertulis yang merupakan dari peningkatan hasil belajar peserta didik lebih diperketat.

\section{Tahap Observasi}

Observasi guru memperoleh skor ratarata pertemuan I $(4,50)$ dan pertemuan II $(4,79)$, observasi peserta didik memperoleh skor ratarata pertemuan I (4,40 dan pertemuan II $(4,67)$. Dampak dari hasil peningkatan hasil belajar dari tugas dan nilai tes tertulis memperoleh nilai rata-rata masing-masing sebesar $(91,70)$ dan $(90,63)$.

\section{Tahap Refleksi}

1. Renungan atas perolehan data hasil observasi guru, observasi peserta didik, dan hasil tes tertulis sebagai dampak dari peningkatan hasil belajar peserta didik di kelas senyatanya.

2. Pengolahan data hasil observasi guru, observasi peserta didik dan tes tertulis

3. Mencocokkan perolehan data hasil tindakan dengan Indikator keberhasilan yang telah ditetapkan.

4. Guru memberikan hadiah/reward kepada semua peserta didik Kelas $\mathrm{V}$ atas keberhasilannya dalam upaya meningkatkan hasil belajar yang berdampak terhadap perolehan hasil belajar sesuai dengan KKM yang telah ditetapkan.

\section{PEMBAHASAN \\ SIKLUS I \\ Tahap Perencanaan}

Peneliti telah berhasil menyusun RPP dengan skenario penerapan pendekatan Index Card Match. Kendala yang dihadapi yaitu dalam penyusunan skenario pembelajaran dengan penekanan peningkatan hasil belajar belajar yang berdampak meningkatnya perolehan hasil belajar. Peneliti telah berhasil menyiapkan alat, sumber, bahan yang diperlukan dalam proses pembelajaran. Sedikit kendala yang dihadapi yaitu dalam penyediaan LCD, faktor penyebabnya karena belum disiapkan tempat permanen sehingga berdampak kurang tepatnya dalam penempatan dan pemasangan. Dalam penyusunan instrument observasi guru maupun instrument observasi peserta didik juga mengaalami kendala, peneliti minta petunjuk kepadaa pengawas pembimbing untuk memberikan 
pembinaan tata cara penyusunan instrument observasi guru maupun penyusunan instrument peserta didik. Dalam penyusunan alat evaluasi, peneliti tidak mengalami hambatan maupun kesulitan. Rumus yang digunakan dalam penentuan keberhasilaan hasil observasi maupun hasil tes tertulis oleh peserta didik dengan menggunakan rumus deskriptif kualitatif.

\section{Tahap Pelaksanaan}

1. Buatlah potongan-potongan kertas sejumlah peserta dalam kelas dan kertas tersebut dibagi menjadi dua kelompok.

2. Tulis pertanyaan tentang materi yang telah diberikan sebelumnya pada potongan kertas yang telah dipersiapkan. Setiap kertas satu pertanyaan.

3. Pada potongan kertas yang lain, tulislah jawaban dari pertanyaan-pertanyaan yang telah dibuat.

4. Kocoklah semua kertas tersebut sehingga akan tercampur antara soal dan jawaban.

5. Bagikan setiap peserta satu kertas. Jelaskan bahwa ini aktivitas yang dilakukan berpasangan. Sebagai peserta akan mendapatkan soal dan sebagian yang lain akan mendapatkan jawaban.

6. Mintalah peserta untuk mencari pasangannya. Jika sudah ada yang menemukan pasangannya, mintalah mereka untuk duduk berdekatan. Jelaskan juga agar mereka memberikan materi yang mereka dapatkan kepada teman yang lain.

7. Setelah semua peserta menemukan pasangan dan duduk berdekatan, mintalah setiap pasangan secara bergantian membacakan soal yang diperoleh dengan suara keras kepada teman-teman lainnya. Selanjutnya soal tersebut dijawab oleh pasangannya. Demikian seterusnya.

8. Akhiri proses ini dengan klarifikasi dan kesimpulan serta tindak lanjut.

Kegiatan pembelajaran diakhiri dengan tes tertulis, hal ini dimaksudkan untuk mengetahui dampak positif dari peningkatan hasil belajar Pendidikan Agama Islam Dan Budi Pekerti peserta didik Kelas V SD Negeri
12 Ampenan Semester satu tahun pelajaran 2018/2019 dengan penerapan pendekatan Index Card Match. Asumsi bila hasil belajar meningkat maka akan berdampak meningkatnya hasil belajar peserta didik.

\section{Tahap Observasi}

Observasi guru memperoleh skor rata-rata pertemuan I $(3,57)$ dan pertemuan II $(3,79)$, sementara Indikator keberhasilan yang diharapkan $(\geq 4,0)$, Hasil observasi peserta didik dalam upaya peningkatan hasil belajar Pendidikan Agama Islam Dan Budi Pekerti peserta didik Kelas V Semester satu tahun pelajaran 2018/2019 di SD Negeri 12 Ampenan diperoleh skor rata-rata pertemuan I $(3,43)$ dan pertemuan II $(3,67)$. Indikator keberhasilan $(\geq$ 4,0 ), Dampak belum meningkatnya hasil belajar peserta didik dilihat dari hasil tugas individual dan hasil tes tertulis yang materinya hanya sekitar yang diajarkan pada saat itu juga, diperoleh nilai rata-rata $(69,13)$ dan $(66,33)$ kategori cukup.

\section{Tahap Refleksi}

Hasil analisa data peningkatan hasil belajar pada siklus I ini $(3,55)$ sedangkan yang diminta dalam Indikator keberhasilan $(\geq 4,0)$, ini artinya belum berhasil. Karena Indikator keberhasilan belum tercapai, penelitian tindakan kelas (PTK) dilanjutkan ke siklus II dengan harapan optimalisasi penerapan strategi pembelajaran dengan model pembelajaran Index Card Match dapat meningkatkan hasil belajar Pendidikan Agama Islam Dan Budi Pekerti peserta didik Kelas V Semester satu tahun pelajaran 2018/2019 di SD Negeri 12 Ampenan.

\section{SIKLUS II}

\section{Tahap Perencanaan}

Peneliti menyusun Rencana Pelaksanaan Pembelajaran (RPP) dengan memperhatikan kesalahan-kesalahan pada siklus I. peneliti lebih memfokuskan tentang Rencana strategi jitu sehingga proses pembelajaran dengan model pembelajaran Index Card Match dapat terelaisasi dengan baik, karenanya dalam penyusunan skenario benar-benar dirinci dari tiap aspek pada proses pembelajaran Index 
Card Match. Sebelum proses pembelajaran dilaksanakan, peneliti menyiapkan semua alat, bahan, dan segala sesuatunya sehingga dalam pelaksanaan proses pembelajaran berjalan sesuai dengan skenario yang telah direncanakan. Agar proses pembelajaran dapat teratasi maka peneliti juga menyiapkan lembar observasi guru dan lembar observasi peserta didik sebagai tolak ukur ketercapaian peningkatan hasil belajar Pendidikan Agama Islam Dan Budi Pekerti peserta didik Kelas V SD Negeri 12 Ampenan.

\section{Tahap Pelaksanaan}

Pada tahap pelaksanaan di siklus II ini pada dasarnya masih mengacu pada pelaksanaan siklus I, yaitu penerapan pendekatan Index Card Match. Bedanya pada siklus ini lebih dioptimalkan.

\section{Tahap Observasi}

Pada siklus II ini hasil observasi memperoleh skor rata-rata pertemuan I $(4,50)$ dan pertemuan II $(4,79)$ sementara Indikator keberhasilan yang diharapkan $(\geq 4,0)$, Upaya meningkatkan hasil belajar Pendidikan Agama Islam Dan Budi Pekerti peserta didik Kelas V Semester satu tahun pelajaran 2018/2019 di SD Negeri 12 Ampenan diperoleh skor rata-rata pertemuan I $(4,40)$ dan pertemuan II $(4,67)$, sementara Indikator keberhasilan yang telah diharapkan adalah $(\geq 4,0)$, Sebagai tolak ukur keberhasilan proses pembelajaran adalah hasil belajar peserta didik meningkat, dari data hasil perolehan nilai rata-rata tugas dan tes tertulis adalah $(91,70)$ dan $(90,63)$ sementara pada siklus sebelumnya hanya $(69,13)$ dan $(66,33)$ berarti mengalami peningkatan yang signifikan.

\section{Tahap Refleksi}

Hasil analisa data peningkatan hasil belajar peserta didik pada siklus II adalah $(4,54)$ sedangkan Indikator keberhasilan $(\geq 4,0)$. Ini artinya pada siklus II hasilnya telah melampaui Indikator keberhasilan sebesar $(0,54)$, sedangkan hasil belajar rata-rata 91,17 dari indikator keberhasilan $\geq 75,00$, artinya telah melampaui indikator keberhasilan yang ditentukan.
Karena Indikator keberhasilan telah terbukti, maka tidak perlu ada upaya perbaikan dan penyempurnaan. Model pembelajaran Index Card Match telah mampu meningkatkan hasil belajar peserta didik yang ditandai dengan tercapainya Indikator keberhasilan dan terjadinya peningkatan hasil belajar peserta didik. "Penelitian Tindakan Kelas (PTK) dihentikan pada siklus II dengan hasil memuaskan."

SIMPULAN

Data komulatif dari hasil penelitian tindakan kelas (PTK) dari siklus I ke Siklus II adalah sebagai berikut:

\begin{tabular}{|c|l|c|c|c|c|c|c|}
\hline \multirow{2}{*}{ No } & \multirow{2}{*}{ Jenis Kegiatan } & \multirow{2}{*}{$\begin{array}{c}\text { Indikator } \\
\text { keberhasilan }\end{array}$} & \multicolumn{2}{|c|}{ Siklus I } & \multicolumn{2}{|c|}{ Siklus II } & \multirow{2}{*}{ Keterangan } \\
\cline { 4 - 6 } & & & I & II & I & II & \\
\hline 1. & Observasi Guru & $\geq 4,00$ & 3,57 & 3,79 & 4,50 & 4,79 & Meningkat \\
\hline 2. & Observasi Peserta didik & $\geq 4,00$ & 3,43 & 3,67 & 4,40 & 4,67 & Meningkat \\
\hline 3. & Tugas Individual & $\geq 75,00$ & 69,13 & 91,70 & Meningkat \\
\hline 4. & Tes tertulis & $\geq 75,00$ & \multicolumn{2}{|c|}{66,33} & 90,63 & Meningkat \\
\hline
\end{tabular}

Penerapan pendekatan Index Card Match sangat efektif upaya untuk meningkatkan hasil belajar Pendidikan Agama Islam Dan Budi Pekerti peserta didik Kelas V Semester satu tahun pelajaran 2018/2019 di SD Negeri 12 Ampenan. Fakta telah menunjukkan perolehan rata-rata skor hasil belajar peserta didik pada siklus I $(3,55)$, sedangkan pada siklus II $(4,54)$, hasil belajar siklus I $(67,73)$ dan Siklus II $(91,17)$ sudah melampaui Indikator keberhasilan yang ditetapkan. Penelitian dinyatakan "berhasil" dan dihentikan pada siklus II.

SARAN

Disarankan kepada guru sejawat untuk melaksanakan Penelitian Tindakan Kelas (PTK) dalam upaya untuk meningkatkan hasil belajar peserta didik sesuai dengan mata pelajaran masing-masing.

Disarankan kepada para semua peserta didik Kelas V SD Negeri 12 Ampenan untuk membiasakan belajar dengan pendekatan yang kontekstual utamanya strategi yang mampu membangkitkan hasil belajar peserta didik yang dampaknya hasil belajar dapat ditingkatkan seperti yang diharapkan.

DAFTAR PUSTAKA

Arikunto, s. 2009, Penelitian Tindakan Kelas, Jakarta : Bumi Aksara. 
Harun Rasyid dan Mansur, 2008, Penilaian Hasil Belajar, Bandung : CV Wacana Prima.

Ismail, 2008, Strategi Pembelajaran Agama Islam Berbasis PAIKEM, Semarang : RaSAIL Media Group.

Lukmanul A, 2008, Perencanaan Pembelajaran, Bandung : CV Wacana Prima.

Mukhtar, 2003, Prosedur Penilaian, Jakarta : Rineka Cipta.

Nurhadi, 2003, Yasin ,B dan Sendule.A, 2003, Kontekstual dan Penerapannya dalam $K B K$, Malang : Unitipetas Negeri Malang.

Robert E Slavin, 2010, Cooperative Learning Teori, riset dan Praktik, Bandung : Nusa Media.

Sardiman, 2007, Indikator Dan Hasil belajar Mengajar, Jakarta : Raja Grafindo Perkasa.

Supriono, 2009, Cooperative Learning Teori dan Aplikasi PAIKEM, Yogyakarta : Pustaka Pelajar. 